\title{
Patients' knowledge and attitudes about the role of anesthesiologists in a military hospital
}

\author{
Bir askeri hastanede anestezistlerin rolü hakkında hastaların bilgi ve tutumları
}

\author{
i. Aydin Erden ${ }^{1}$, Recep Tütüncü̈
}

\begin{abstract}
ABSRACT
Objectives: We designed a study to assess the Turkish patients' understanding and knowledge on the anesthesiologist's role and to evaluate the influence of the patient's prior education, preoperative anxiety and experience with anesthesia on such understanding.
\end{abstract}

Materials and Methods: Two hundred adult patients undergoing general anesthesia for surgery, from September to December 2008 at Etimesgut Military Hospital were enrolled in the study. A self-administered structured questionnaire distributed to patients waiting for preoperative evaluation.

Results: Only $40 \%$ of respondents knew that the anesthesiologist was a doctor. There was a relationship between the level of education and the knowledge of the patient regarding whether the functions and responsibilities of an anesthesiologist in the hospital.

Conclusions: The responses have shown poor knowledge of the public regarding the role of anesthesiologists. It indicates a need for exposure of the specialty to patients that can increase patient's knowledge that may help to decrease preoperative anxiety. J Clin Exp Invest 2012; 3(3): 313-317

Key words: Anesthesiologist, patient, knowledge

\section{INTRODUCTION}

The discipline of anesthesia, despite having developed to encompass intensive care, pain management, and trauma care, still there is not enough public exposure regarding the role of anesthesiologists. Moreover, the public image of anesthesiologist is so poor that many do not know if an anesthesiologist is a medically qualified physician. In a survey of 100 consecutive surgical patients in a British hospital where all anesthesia is provided by anesthesiologists, only $65 \%$ thought that the anesthesiologist

\section{ÖZET}

Amaç: Biz bu çalışmada Türk hastaların anestezistlerin görevlerini anlama ve bu konuda bilgi düzeylerini değerlendirmek ve hastaların eğitim düzeyi, preoperatif anksiyete ve anesteztezi tecrübelerinin bu konudaki bilgilerine etkilerini araştırmayı amaçladık.

Gereç ve Yöntem: Etimesgut Asker Hastanesinde 2008 yılı Eylül Aralık ayları arası cerrahi için genel anestezi alacak 200 hasta çalışmaya dahil edildi. Preoperatif değerlendirme için bekleyen hastalara anket uygulandı.

Bulgular: Cevap verenlerden sadece \%40'I anestezistin doktor olduğunu biliyordu. Hastaların eğitim seviyesiyle anestezistlerin hastanedeki fonksiyon ve sorumlulukları hakkında bilgileri arasında ilişki vardı.

Sonuç: Sonuçlar halkın anestezistlerin rolü hakkında düşük bilgi seviyesine sahip olduğunu göstermiştir. Bu nedenle uzmanlığın hastalara daha fazla anlatılması gerekmektedir. Böylece hastaların bilgileri artabilir ve bu da preoperatif anksiyetenin azalmasına yardımcı olabilir.

Anahtar kelimeler: Anestezistin rolü, hasta, bilgi

was a doctor. ${ }^{1}$ The widespread role of anesthesiologist and current breadth of aesthetic practice is not known to the public and even other healthcare personnel. Usually, they have very limited knowledge about the specialty. ${ }^{2,3}$ Although, anesthesiologists recognize the difficulty that the rest of the world has in identifying just what an anesthesiologist is, with the explosive growth of media such as television and the internet over the recent past, there may be a possible increased awareness among the public.

In addition, true and sufficient knowledge supply about anesthesiologists and anesthesia is an

${ }^{1}$ Etimesgut Asker Hastanesi, Anesteziyoloji ve Reanimasyon Kliniği, Ankara, Türkiye

${ }^{2}$ Etimesgut Asker Hastanesi, Psikiyatri Kliniği, Ankara, Türkiye

Correspondence: İ. Aydın Erden,

Hacettepe Üniversitesi Tıp Fakültesi Anesteziyoloji ve Reanimasyon AD, Ankara, Türkiye Email: aydinerden@yahoo.com Received: 29.05.2012, Accepted: 15.08.2012

Copyright (C) JCEI / Journal of Clinical and Experimental Investigations 2012, All rights reserved 
effective way in reducing anxiety and cope with it. Anxiety is an important issue especially in preoperative period. In a study preoperative anxiety levels were found inversely associated with postoperative satisfaction and better recovery. ${ }^{4,5}$

Therefore we designed a study to assess the Turkish patients' understanding and knowledge of the anesthesiologist's role and to evaluate the influence of the patient's prior education, preoperative anxiety and experience with anesthesia on such understanding. To our knowledge, there are no published reports from the Turkey regarding the attitudes about the specialty and its different roles.

\section{MATERIALS AND METHODS}

Following institutional review board approved, prospective study, 200 adult (>16 years-old) patients undergoing general anesthesia for surgery, from September to December 2008 at Etimesgut Military Hospital were enrolled in the study. Exclusion criteria were refusal to participate, language difficulties, or lack of sufficient mental capacity because of poor health. Patients who agreed to participate in the study gave their written informed consent.

A self-administered structured questionnaire consisted of 12 multiple choice questions related to the functions and responsibilities of an anesthesiologist in the hospital and 5 multiple choice questions related to the patients' knowledge about the anesthesiologist, distributed to patients waiting for preoperative evaluation. Demographic data including age, gender, marital status, educational level and previous anesthesia experience, where they have heard about anesthesia, were also obtained. Initially, a pilot study was conducted with a selected group of patients who were asked to fill out the questionnaire and return it with comments and criticism. Minor changes were made to the final instrument. The completed questionnaires were collected and coded to maintain anonymity and confidentiality of the respondent.

Anxiety was measured with Beck Anxiety Inventory and State Trait Anxiety Inventory (STAI). ${ }^{6}$ STAI is a widely used self-report instrument that estimates situational and baseline anxiety in adults on the basis of responses to 40 statements. Testretest correlations for the STAI are reported to be high, ranging from 0.73 to 0.86 . Its Turkish reliability and validity was also studied. ${ }^{7}$ The Beck Anxiety Inventory (BAI), designed by Aaron T. Beck, is a 21-question multiple-choice self-report inventory that is used for measuring the severity of an individual's anxiety. ${ }^{8}$ Reliability and validity of its Turkish was also made. ${ }^{9}$

\section{Statistical analysis}

Data were analyzed with SPSS software version 11.5 (SPSS Inc, Chicago, IL). The one-sample Kolmogorow-Simirnov test was used for determining whether the data were normally distributed. For parametric variables, a t-test on two independent samples was used to compare two groups. For non-parametric variables, the Mann-Whitney-U-test was used to compare two groups. For categorical variables comparing among the groups Pearson's Chi-square or Fisher's exact test were used. Unless noted otherwise, data were presented as mean with standard deviation (SD). Statistical significance was set at the level of $P<0.05$.

\section{RESULTS}

Totally 200 questionnaires were completed. Overall, there were equal female respondents $(50 \%)$ to male respondents $(50 \%)$. The age of respondents ranged from 20 to 77 years and older. Of the patients, $51 \%$ fell in the age group of 20 to 22 years, $28.5 \%$ in the 23 to $30,12,5 \%$ in the 31 to $40,2 \%$ in the 41 to $50,2 \%$ in 51 to $60,3 \%$ in the 61 to 70 , and $1 \%$ in the 71 years and older. Educational level of the respondents ranged across the entire spectrum of primary to university. Most of the respondents had high school level education. There was a significant difference between the level of education and the knowledge of the patient regarding whether the anesthesiologist was a medically qualified doctor. With respect to past surgical experience, $57.5 \%$ of the respondents answered that they were waiting for the first surgery, $42.5 \%$ had surgery in the past.

Table 1 lists patients' knowledge about the anesthesiologist Table 2 shows the response options to questions relating to the various functions and responsibilities of an anesthesiologist in the hospital. There was a significant relationship between the level of education and the knowledge of the patient regarding whether the functions and responsibilities of an anesthesiologist in the hospital. However, there was no relationship between past surgical experience with the functions and responsibilities of an anesthesiologist. Also, there was no significant relationship between the level of education and past surgical experience with the patients' knowledge about the anesthesiologist. 
Table 1. Results of knowledge about the anesthesiologist

Question 1: In your opinion the anesthesiologist is:
a. A nurse
b. A technician
c. A doctor

Question 2: Who will administer the anesthetic drugs?
a. A nurse
b. A technician
c. The anesthesiologist her/himself

Question 3: Who will ensure your well-being (keep vital signs) during the operation?
a. A nurse
b. A technician
c. The anesthesiologist

Question 4: Who will be responsible for your safe recovery at the end of the operation?
a. A nurse technician
b. Technician in control of an anesthesiologist
c. Technician in control of a surgeon

Question 5: In what areas in the hospital does the anesthesiologist take care of patients?

a. Only in the operating room

b. Pain clinic

c. Intensive care units

d. Resuscitation

e. All answers are correct

Table 2. Role of Anesthesiologist

\begin{tabular}{lccc}
\hline Function of an Anesthesiologist & $\begin{array}{c}\text { Yes } \\
(\%)\end{array}$ & $\begin{array}{c}\text { No } \\
(\%)\end{array}$ & $\begin{array}{c}\text { Do not } \\
\text { know } \\
(\%)\end{array}$ \\
\hline Transports emergency patients & 18 & 20.5 & 61.5 \\
Resuscitates patients & 15.5 & 30.5 & 54 \\
Has a role in the ICU & 35.5 & 15.5 & 49 \\
Determines fitness for surgery & 64 & 6.5 & 29.5 \\
Obtains written consent & 38 & 3.5 & 58.5 \\
Monitors vital signs during surgery & 56.5 & 6.5 & 37 \\
Injects medication during surgery & 40 & 11.5 & 48.5 \\
Monitors blood loss during surgery & 23 & 25 & 52 \\
Transfuses blood when needed & 13 & 33 & 54 \\
Ensures that patient wakes up & 43.5 & 9.5 & 47 \\
Without any problem & & 16 & 64 \\
Ensures that patient is not vomiting & 20 & 16 & 55 \\
\hline Ensures that patient is pain-free & 31.5 & 13.5 & 55 \\
\hline
\end{tabular}

$\mathrm{ICU}=$ Intensive care unit
In terms of anxiety scores, the results were as follows: University graduates had significantly lower scores in trait and beck anxiety scales $(p=0,002$ and $p=0,048$ respectively). There was no significant difference in anxiety scores according to operation history. Trait anxiety scores were significantly higher in patients who knew the anesthesiologist as a nurse $(p=0,016)$. The patients thought "Technician is responsible for safe recovery" had significantly higher state anxiety scores than the ones said doctor was responsible for it $(p=0,035)$. The results related to anesthesiologist's roles showed that the ones signed "Anesthesiologist determines fitness for surgery" had lower trait anxiety scores than the ones signed "No" and "Do not know" $(p=0,001)$; and they had lower state anxiety scores than the ones signed "No" $(p=0,030)$. Patients signed "Anesthesiologist obtains written consent" choice had significantly lower state and trait anxiety scores $p=0,029$ and $p=0,039$ respectively than the ones signed "No". The patients' knowledge "Anesthesiologist monitors vital signs during surgery" was significantly related with lower state $(p=0,013)$ and beck anxiety scores $(p=0,029)$ than the patients with no knowledge. Similarly, the patients' knowledge "Anesthesiologist ensures that patient wakes up without any problem" was significantly related to lower state $(p=0,036)$ and beck anxiety scores $(p=0,013)$ than the patients with no knowledge.

\section{DISCUSSION}

Anesthesiology as a medical specialty had its beginnings in the early part of last century. It has evolved into a recognized medical specialty providing continuous improvement in the basic and medical sciences. Anesthesiologists' role extends beyond the operating room to include intensive care, pain management and preoperative evaluation. However, the general public knew little of these developments. ${ }^{2}$

In the present study, only $40 \%$ of respondents knew that the anesthesiologist was a doctor compared with $59 \%$ in the Carabian, $65 \%$ in the UK and, $88.7 \%$ in the USA. ${ }^{1,10,11}$ This is a disappointing finding of our study. However, there are many possible reasons for this observation. One of the reasons may be the lower socioeconomic status and level of education of the patients we surveyed. Second, they were not well informed about medical qualifications of anesthesiologists at the previous preanesthetic visit. However, this problem isn't just seen in anesthesiology. Savaş et al ${ }^{12}$ stated that discrimination of psychiatrist and psychologist were not defined well in a big proportion in Turkey also. 
To increase awareness of the public television and internet can be used more efficiently.

Swinhoe and Groves have shown that $79 \%$ of patients believed that the anesthesiologist was primarily responsible for their well-being. ${ }^{1}$ In contrast, in our study this rate was just $7.5 \%$. Also, administration of anesthetic drugs by the anesthesiologist was not known. These questions might have confused patients. Because the notion of "well-being during operation" could mean very different things to different people. It could, for example refer to well-being from a surgical operative standpoint. Another reason might be our patients thought that, technicians do the work and anesthesiologists control them.

In consistent with the Israeli patients' nearly half of the Turkish patients recognized the Anesthesiologist's involvement in the assurance of safe recovery. ${ }^{13}$ However, the other half of Turkish patients thought that surgeon was responsible. This might be due to in some hospitals still surgeons might be giving information about surgery and anesthesia together.

Another disappointing finding of the present study is the knowledge regarding the anesthesiologist's role outside the operating theatre such as in intensive care, on obstetric units, acute and chronic pain management, teaching, education and resuscitation. However, anesthesiologists have many other duties outside the operating room, the majority of our patients were convinced that the operating ward was the only working place of the anesthesiologist in Turkey. Our results also consistent with Israeli patients' answers. ${ }^{13}$ This finding means that we are very poor at explaining our duties to the public. Poor public image is one of the reasons for job dissatisfaction of an anesthesia resident and medical students hesitate to join an anesthesiology program. ${ }^{14}$ It is obviously important that we enlighten the public and others in the medical profession of our role outside the theatre complex.

Anxiety is also an important issue related to obtained information preoperatively. It is well recognized that information helps some people cope better with their anxieties and enable to comply better with the post treatment constraints and to recognize and act appropriately in any possible complications..$^{15}$ In our study, we found that university graduates were less anxious than the others. In the literature, strong relationship is reported between degree of understanding and educational level. ${ }^{16}$ So the patients with higher education could know more about anesthesiologists, and could use coping mechanisms more effectively. In this respect, physicians should be cautious of the fact that lower educated patients may have insufficient information about anesthesiologists and may ask for more information.

In our study, it is highlighted that many false knowledge especially about the anesthesiologists' identity, roles in safe recovery, determining fitness for surgery, obtaining written consent, monitoring vital signs during surgery had significant relationship with various anxiety conditions. Therefore, information provision is a particularly effective and appropriate approach to reducing the occurrence of anxiety and helping patients to cope with anxiety when it does occur. Patients that have been provided with information pre-operatively have been shown to experience less nausea and vomiting, have fewer post-operative complications, require less pain medication and have shorter hospital stays. ${ }^{5}$

As a limitation of the present study, it is a single center study and may not reflect the whole country attitudes toward anesthesiologists, whereas can give an idea of Turkish patients knowledge.

In conclusion, our study has shown poor knowledge of the public regarding the role of anesthesiologists. The responses indicate a need for exposure of the specialty to patients, making use of media and internet. Moreover, involvement of the anesthesiologist in patient education with the introduction of preanesthetic clinics, routine preoperative and postoperative visits can increase patient's knowledge and decrease anxiety associated with anesthesia and anesthesiologists.

\section{REFERENCES}

1. Swinhoe CF, Groves ER. Patients' knowledge of anaesthetic practice and the role of anaesthetists. Anaesthesia 1994;49(2):165-6.

2. Simini B. Anaesthetist: the wrong name for the right doctor. Lancet 2000;355(234):1892.

3. Cooper GM, Hutton P. Anaesthesia and the undergraduate medical curriculum. Br J Anaesth 1995;74(1):3-5.

4. Hobson JA, Slade P, Wrench IJ, Power L. Preoperative anxiety and postoperative satisfaction in women undergoing elective caesarean section. Int $\mathrm{J}$ of Obst Anest 2006;15(1):18-23.

5. Scott A. Managing anxiety in ICU patients: the role of pre-operative information provision. Nursing in Critical Care 2004;9(2):72-9.

6. Spielberger CD, Gorsuch RL, Luchens RE. Manual for the State-Trait Anxiety Inventory. Palo Alto, CA: Consulting Psychologists Press; 1970.

7. Öner N, Le Compte A(1983) Durumluk Sürekli Kaygı Envanteri El Kitabı, 1. Basım. İstanbul: Boğaziçi Üniversitesi Yayınları; 1983. 
8. Beck AT, Epstein N, Brown G, Steer RA. An inventory for measuring clinical anxiety: psychometric properties. J Consult Clin Psychol 1988 ;56(6):893-7.

9. Ulusoy M, Şahin N, Erkmen H. Turkish Version of The Beck Anxiety Inventory: Psychometric Properties. J Cogn Psychot 1998;12(2):163-72.

10. Hariharan S, Merritt-Charles L, Chen D. Patient perception of the role of anesthesiologists: a perspective from the Caribbean. J Clin Anesth 2006;18(7):504-9.

11. Shevde K, Panagopoulos G: A survey of 800 patients' knowledge, attitudes, and concerns regarding anesthesia. Anesth Analg 1991;73(2):190-8.

12. Savaş HA, Yumru M, Göral L, Özen ME. Information and attitudes associated with psychiatry and psychology in the context of psychiatric disorders in southeast of Turkey: a crossection from Gaziantep city. Anatolian J Psychiatry 2006; 7(2):140-9.
13. Calman LM, Mihalache A, Evron S, Ezri T. Current understanding of the patient's attitude toward the anesthesiologist's role and practice in Israel: effect of the patient's experience. Clin Anesth 2003;15(6):451-4.

14. Irwin MG, Soon NT, Fung SK. A profile of anaesthesia trainees in Hong Kong. Hong Kong Med J 2001;7(2):227-35.

15. Patrick JD, Dawes BS. Informed consent: what do patients want to know? J Royal Soc Med 1994;87(1):14952.

16. Vila JJ, Jiménez FJ, Inarrairaegui M, Prieto C, Nantes O, Borda F. Informed consent document in gastrointestinal endoscopy: understanding and acceptance by patients. Rev Esp Enferm Dig 2006;98(2):101-11. 